study showed a significant reduction in lower oesophageal sphincter pressure after intramuscular administration of emepronium bromide. In the nine patients who completed the study no significant change in sphincter pressure was found after four weeks' treatment with a standard oral dose of emepronium bromide. This may have been due to the much lower serum concentrations seen after oral medication than after intramuscular injection, confirming the findings of Ritch et al. ${ }^{5}$

A local irritative effect of the tablets is probably the most common cause of oesophageal injury after oral medication, as no decrease in sphincter pressure was shown during oral treatment with emepronium bromide. Since, however, higher plasma concentrations of emepronium bromide decrease the sphincter pressure and the absorption of the drug from the gastrointestinal tract varies considerably, occasional high serum concentrations may be seen. This, combined with an individual variability in parasympathetic receptor sensitivity, might cause the lower oesophageal sphincter to relax, causing more severe cases of reflux oesophagitis in the lower oesophagus.

${ }^{1}$ Hebjern S, Anderson JT, Walter S, Dam AM. Detrusor hyperreflexia. Scand $\mathcal{F}$ Urol Nephrol 1976;10:103-9.

${ }^{2}$ Collins JF, Matthews HR, Baker SE, Strakova JM. Drug-induced oesophageal injury. $\mathrm{Br} \mathrm{Med} \mathcal{F} 1979 ; \mathrm{i}: 1673-6$.

${ }^{3}$ Siemssen OJ. Measurements of lower oesophageal sphincter pressure (LESP) by means of a triple intraluminal probe. Acta Chir Scand $1979 ; 145$, suppl 487:65.

4 Dodds WJ, Hogan WJ, Stef JJ, Miller WN, Lydon SB, Arndorfer RC. A rapid pull-through technique for measuring lower esophageal sphincter pressure. Gastroenterology 1975;68:437-43.

${ }^{5}$ Ritch AES, Castleden CM, George CF, Hall MRP. A second look at emepronium bromide in urinary incontinence. Lancet 1977;i:504-6.

(Accepted 3 March 1981)

Department of Surgical Gastroenterology, Herlev Hospital, University of Copenhagen, Denmark

OLE J SIEMSSEN, MD, registrar

Urological Laboratory, Department of Urology, Herlev Hospital, University of Copenhagen, Denmark

JENS T ANDERSEN, MD, senior registrar

HANS H MEYHOFF, MD, senior registrar

JØRGEN NORDLING, MD, senior registrar

STEEN WALTER, MD, senior registrar

\section{Acute severe intravascular haemolysis: an unrecognised cause of pancreatitis}

Pancreatitis or histologically proved pancreatic damage is common in chronic renal failure ${ }^{1}$ and complicates $3-7 \%$ of renal transplant operations. ${ }^{2}$ Hypercalcaemia as a result of hyperparathyroidism, hyperlipidaemia, and viral infections may be contributing factors in uraemic patients. ${ }^{3}$ Occasionally drugs-corticosteroids, cytotoxic agents, or thiazides-may be a factor.

We describe two patients receiving haemodialysis in whom acute pancreatitis developed in association with acute intravascular haemolysis owing to the use of hypotonic dialysate.

\section{Case reports}

CASE 1

A 42-year-old woman who had been receiving regular hospital haemodialysis for three months owing to end-stage renal failure secondary to reflux nephropathy complained of being unwell with central chest pain and diaphoresis 100 minutes into a dialysis session. Dark red blood was evident in the dialysis lines. She had no history of any viral illness or excessive ethanol ingestion. Her only medication was aluminium hydroxide gel $950 \mathrm{mg}$ thrice daily. Physical examination was unremarkable except for moderate epigastric tenderness. Laboratory investigations showed packed cell volume $21 \%$, serum sodium $109 \mathrm{mmol}(\mathrm{mEq}) / 1$, dialysate sodium $35 \mathrm{mmol} / \mathrm{l}$, serum amylase activity $2000 \mathrm{U} / \mathrm{l}$, and serum calcium $2.5 \mathrm{mmol} / 1(10 \mathrm{mg} / 100 \mathrm{ml})$. The plasma in a centrifuged specimen was pink. Dialysis was stopped immediately.

She was initially treated with $3 \%$ sodium chloride solution and dialysate containing $145 \mathrm{mmol}$ sodium $/ 1$. She complained of increasing epigastric pain radiating into her back over the ensuing 24 hours. Physical examination showed increasing epigastric tenderness with paralytic ileus. Dilated loops of small bowel were seen on an abdominal $x$-ray film; serum amylase activity had increased to $10000 \mathrm{U} / 1$. Clinical and biochemical variables gradually resolved over the next five days, treatment comprising nasogastric aspiration, intravenous fluids, and cimetidine. She remained well over the next six months and resumed hospital dialysis.

\section{CASE 2}

A 30-year-old man who had received home haemodialysis for four years was admitted because of failing vascular access. He complained of feeling hot, chest tightness, and dyspnoea 210 minutes into a dialysis session. Dark red blood was noted in the dialysis lines. A history of recent viral infection or ethanol ingestion was absent. His only medication was aluminium hydroxide tablets $375 \mathrm{mg}$ thrice daily. Physical examination showed epigastric tenderness. Laboratory investigations showed serum sodium $115 \mathrm{mmol} / 1$, serum chloride $83 \mathrm{mmol}(\mathrm{mEq}) / \mathrm{l}$, dialysate sodium $30 \mathrm{mmol} / 1$, serum amylase $6600 \mathrm{U} / 1$, and serum calcium $2 \cdot 25 \mathrm{mmol} / 1(9 \mathrm{mg} / 100 \mathrm{ml})$. Centrifugation of a blood sample yielded pink plasma. Dialysis was immediately stopped. He was treated with $3 \%$ hypertonic sodium chloride solution, and dialysis was restarted with dialysate containing $145 \mathrm{mmol}$ sodium/l.

He complained of increasing epigastric pain over the next 24 hours, developing paralytic ileus. Serum amylase activity was $17600 \mathrm{U} / 1$. His symptoms resolved over the next eight days with nasogastric aspiration, intravenous fluids, cimetidine, and analgesia. He remained well four months later, having resumed home haemodialysis. Barium-meal examination was normal.

\section{Comment}

Pancreatitis may be hard to diagnose in uraemic patients as serum amylase activity is commonly increased, usually less than threefold. Confirmation may be achieved by using the amylase to creatinine clearance ratio. ${ }^{4}$ The absence of a history of recent viral infection and ethanol ingestion, with normocalcaemia and satisfactory clearance on dialysis, exclude these as aetiological factors. The pathophysiology of haemolysis-induced pancreatitis is due to local release of intracellular lysozomal enzymes, especially cathepsin B, resulting in activation of trypsinogen and other zymogens with the sequelae of autodigestion and inflammation. Nevertheless, a further underlying risk factor may also be necessary, which in our cases was the uraemic state.

Although the intravascular haemolysis in our patients was due to human error in a recirculating single-pass positive-pressure system, its association with pancreatitis has not to our knowledge been reported before. We emphasise the importance of this complication, which may be prevented by strict attention to proper dialysis procedures and adequate treatment of water. ${ }^{5}$

${ }^{1}$ Avram MM. High prevalence of pancreatic disease in chronic renal failure. Nephron 1977;18:68-71.

${ }^{2}$ Corrodi P, Knoblauch M, Binswanger U, Schölzel E, Largiedèr F. Pancreatitis after renal transplantation. Gut 1975;16:285-9.

${ }^{3}$ Hermon-Taylor J. An aetiological and therapeutic review of acute pancreatitis. Br $\mathcal{F}$ Hosp Med 1977;18:546-52.

${ }^{4}$ Levitt MD, Rapoport M, Cooperband SR. The renal clearance of amylase in renal insufficiency, acute pancreatitis and macroamylasemia. Ann Intern Med 1969;71:919-25.

5 Schuett H, Port FK. Haemolysis in haemodialysed patients. Dialysis and Transplantation 1980;9:345-7.

(Accepted 13 March 1981)

The Charitable Infirmary, Dublin 1

J F WALKER, MB, MRCPI, registrar to renal unit

C J CRONIN, MB, MRCPI, registrar to professorial unit

J F DONOHOE, MD, FACP, consultant nephrologist

M CARMODY, MD, FRCPI, consultant nephrologist

W F O'DWYER, MD, FRCPI, professor of medicine

\section{Comparative risks of rhesus autoimmunisation in two different methods of mid-trimester abortion}

The introduction of anti-D immunoglobulin has greatly reduced the incidence of rhesus haemolytic disease, though cases still occur. ${ }^{1}$ Autoimmunisation after spontaneous or induced abortion is an important factor and can probably be prevented: anti-D immunoglobulin is not always given to Rh-negative women. ${ }^{2}$ Autoimmunisa- 